\title{
Conjunctural hunger and structural obesity in the global scenario: reflections on what Covid-19 masks reveal
}

\section{Fome conjuntural e obesidade estrutural \\ no cenário global: reflexões sobre o que revelam as máscaras da Covid-19}

\author{
Aline Miroski de ABREU1 (iD) 0000-0003-0006-8999 \\ Carina Carlucci PALAZZO² (iD) 0000-0001-5963-4401 \\ Bernardo Paz BARBOZA ${ }^{1}$ (iD 0000-0002-0080-1452 \\ Elisabeth WAZLAWIK1 ${ }^{1}$ (D) 0000-0001-7462-3399 \\ Rosa Wanda DIEZ-GARCIA ${ }^{3}$ (iD) 0000-0002-7062-974X \\ Francisco de Assis Guedes de VASCONCELOS'1 (iD) 0000-0002-6162-8067
}

\footnotetext{
${ }^{1}$ Universidade Federal de Santa Catarina, Centro de Ciências da Saúde, Programa de Pós-Graduação em Nutrição. Campus Universitário Reitor João David Ferreira Lima, 88040-900, Florianópolis, SC, Brazil. Correspondence to: FAG VASCONCELOS. <f.vasconcelos@ ufsc.br>.

${ }^{2}$ Universidade de São Paulo, Faculdade de Medicina de Ribeirão Preto, Programa de Pós-Graduação em Clínica Médica. Ribeirão Preto, SP, Brazil.

${ }^{3}$ Universidade de São Paulo, Faculdade de Medicina de Ribeirão Preto, Departamento de Ciências da Saúde, Divisão de Nutrição e Metabolismo. Ribeirão Preto, SP, Brazil.

Support: The authors FAG Vasconcelos (Case: 303233/2019-2) and RW Diez-Garcia (Case: 303194/2018-9) are grateful to the Conselho Nacional de Desenvolvimento Científico e Tecnológico (CNPq, National Council for Scientific and Technological Development) for the Productivity Scholarships; the authors Abreu, A.M., Palazzo C.C.; and Barboza, B.P,are grateful for the support of the Coordenação de Aperfeiçoamento de Pessoal de Nivel Superior (CAPES, Coordination for the Improvement of Higher Education Personnel) - Brazil (Funding 001).
}

\section{How to cite this article}

Abreu AM, Palazzo CC, Barboza BP, Wazlawik E, Diez-Garcia RW, Vasconcelos FAG. Conjunctural hunger and structural obesity in the global scenario: reflections on what Covid-19 masks reveal. Rev Nutr. 2021;34:e200221. https://doi.org/10.1590/1678-9865202134e200221 
This essay is a reflection on the interconnection of the Covid-19 pandemic, social inequality, food insecurity and obesity in the global scenario. The pandemic health crisis is bound to an economic and social crisis marked by an increase in unemployment and a decrease in income with a consequent growth of food and nutritional insecurity. The impacts are felt worldwide, although the situation in each country, with regard to the conditions of social inequality and access to food, influences the magnitude of the pandemic consequences. At the same time, we are aware that food and nutritional insecurity is associated with low food quality and higher rates of obesity, which impairs the immune response and predisposes to worse prognosis. Thus, more economically vulnerable populations must face poorer disease outcome, besides the worsening of the economic situation and food and nutritional insecurity and the increase in obesity rates.

Keywords: Covid-19. Food and nutritional insecurity. Obesity. Pandemic.

\section{RESUMO}

Este ensaio traz uma reflexão sobre a inter-relação da pandemia da doença causada pelo novo coronavírus com a desigualdade social, a insegurança alimentar e a obesidade no cenário global. A crise sanitária oriunda da pandemia está atrelada a uma crise econômica e social, marcada pelo aumento do desemprego e pela diminuição da renda, com consequente acréscimo da insegurança alimentar e nutricional. Os impactos devem ser sentidos em todo o mundo, embora a situação de cada país, no que diz respeito às condições de desigualdade social e acesso à alimentação, influencie na magnitude dos efeitos da pandemia. Paralelamente, sabe-se que a insegurança alimentar e nutricional está associada à baixa qualidade alimentar e a maiores índices de obesidade, o que prejudica a resposta imunológica e predispõe a piores prognósticos. Dessa forma, populações mais economicamente vulneráveis devem encarar piores desfechos da doença, além do agravamento da situação econômica, da piora da IAN e do aumento dos índices de obesidade.

Palavras-chave: Covid-19. Insegurança alimentar e nutricional. Obesidade. Pandemia.

\section{INTRODUTION}

Within the global framework, the Coronavirus Disease 2019 (Covid-19) pandemic has been devastating a number of sectors, strongly impacting the economy and exacerbating social inequalities among countries and people [1-3].

According to the United Nations (UN), it was estimated that 34.3 million people would fall below the extreme poverty line in 2020 (per capita income less than US\$1.90 per day). The health crisis generated by the pandemic affects the most vulnerable populations, a condition that exposes them to Food and Nutritional Insecurity (FNI) and to Covid-19 infection susceptibility [4].

In the array of problems that stand behind the risk of complications from Covid-19, the following can be evidenced: (i) the vulnerability of socioeconomic situations that cause impacts on the quality of life and food, as well as of the stress conditions related to uncertainties and poverty [5,6]; (ii) the impairment of food quality, directly affected by impoverishment, fostering the consumption of cheaper, ultra-processed foods with low nutrient quality [7]; (iii) the conditions for the increase in the prevalence of obesity due to the poor quality of food, stress and limitations generated by emerging social problems associated with social confinement, such as sedentary lifestyle $[8,9]$.

In the global scenario, up to April 19, 2021, 141,057,106 confirmed cases and 3,015,043 deaths from Covid-19 have been recorded, with the five highest mortality rates affecting the United States of America, Brazil, Mexico, India and the United Kingdom [10].

The purpose of this essay is to reflect on the interrelationship between the Covid-19 pandemic, social inequality, food insecurity and obesity in the global scenario. 


\section{METHODS}

This is an essay carried out based on the review of public official data, technical documents and nonsystematic bibliographic review, with the collection period from June 1, 2020 to April 19, 2021. Exploratory searches were carried out in databases such as PubMed and SciELO, as well as in the official pages of national and international organizations and institutions, and also in news from newspapers and other media. Comparative analyses of sociodemographic and health indicators between specifically selected countries like Brazil, China, the United States of America, Italy and Sweden were carried out. Due to the current, contemporary and dynamic subject investigated, this study did not mean to be exhaustive; it was sought only as a brief approximation that would spur reflections and debates in the academic fields involved.

\section{SOCIAL INEQUALITIES AND FOOD AND NUTRITIONAL INSECURITY DURING THE COVID-19 PANDEMIC}

The effects of the Covid-19 pandemic on social inequality and the disease consequences show how social suffering can be expressed in biological (individual) manifestations. The set of problems that act synergistically, enhancing the risks and severity of Covid-19 infection, can be extended to the influence of social policies and indicators, according to the data comparison between different countries presented in Table $1[2,11]$.

Observing the situations of Brazil and the United States of America (USA), for example, it is noteworthy that despite Brazil being one of the countries most affected by Covid-19 until April 19, 2021, with more than 13 million infections and more than 370,000 deaths Brazil still ranks behind the USA, which although a developed country, has already reached more than 31 million infected people and 560,000 deaths [10]. It is noteworthy that both countries initially resisted to adhere to stricter protective strategies against the pandemic. Unfortunately, after more than a year of pandemic, Brazil is in a catastrophic situation in cases of death per 100 thousand inhabitants (Table 1). In the world context, we can perceive the beneficial effect of mass vaccination and other sanitary and economic measures adopted in some countries, such as the USA in April 2021. Prioritization of vaccination by the new North American government, resulted in a sharp decline

Table 1 - Sociodemographic and health indicators of different countries affected by the Coronavirus disease pandemic 2019 (Covid-19).

\begin{tabular}{|c|c|c|c|c|c|}
\hline Indicators & Brazil & Sweden & Italy & China & United States \\
\hline Total population (inhabitants) [62] & $211,049,527$ & $10,285,453$ & $60,297,396$ & $1,397,715,000$ & $328,239,523$ \\
\hline Population $\geq 65$ years old [62] & $\begin{array}{l}19,525,475 \\
(9.3 \%)\end{array}$ & $\begin{array}{c}2,077,514 \\
(20.2 \%)\end{array}$ & $\begin{array}{l}13,875,719 \\
(23 \%)\end{array}$ & $\begin{array}{c}160,348,563 \\
(11.5 \%)\end{array}$ & $\begin{array}{l}53,206,334 \\
(16.2 \%)\end{array}$ \\
\hline $\begin{array}{l}\text { Obese population > } 18 \text { years old (prevalence) } \\
\mathrm{BMI} \geq 30 \mathrm{~kg} / \mathrm{m}^{2} \text { in } 2016 \text { [22] }\end{array}$ & $22.1 \%$ & $20.6 \%$ & $19.9 \%$ & $6.2 \%$ & $36.2 \%$ \\
\hline IDH (2018) [20] & 0.761 & 0.937 & 0.883 & 0.758 & 0.92 \\
\hline Unemployment rate (2020) [62] & $12 \%$ & $6.7 \%$ & $9.8 \%$ & $4.4 \%$ & $3.9 \%$ \\
\hline Extreme poverty rate (per capita income <US\$1.90/day) [23] & $4.4 \%(2018)$ & $\begin{array}{l}0.2 \% \\
(2017)\end{array}$ & $\begin{array}{l}1.4 \% \\
(2017)\end{array}$ & $0.5 \%(2016)$ & $1.0 \%(2016)$ \\
\hline Undernourished people (millions) period 2015-2017 [21] & $<5.2$ & $<0.2$ & $<1.5$ & 124.5 & $<8.1$ \\
\hline $\begin{array}{l}\text { Undernourished people (prevalence of total population) } \\
\text { period 2017-2019 [22] }\end{array}$ & $<2.5 \%$ & $<2.5 \%$ & $<2.5 \%$ & $<2.5 \%$ & $<2.5 \%$ \\
\hline Total infected by confirmed Covid-19 in 04/19/2021 [10] & $13,900,091$ & 900,138 & $3,870,131$ & 103,315 & $31,311,941$ \\
\hline Total deaths by confirmed Covid-19 in 04/19/2021 [10] & 371,678 & 13,788 & 116,927 & 4,856 & 561,616 \\
\hline $\begin{array}{l}\text { Total deaths by confirmed Covid-19 (per 100,000 } \\
\text { inhabitants) in 04/19/2021 [10] }\end{array}$ & 174.86 & 133.51 & 196.05 & 0.33 & 169.67 \\
\hline Vaccine doses administered up to $04 / 21 / 2021$ [10] & $32,394,085$ & $2,581,989$ & $15,166,198$ & $188,090,000$ & $202,553,704$ \\
\hline
\end{tabular}

Note: >: Bigger or equal; >: Bigger; <: Smaller BMI: Body Mass Index; HDI: Human Development Index; 
in the number of deaths from Covid-19 [10-14]. In Brazil, until now, no effective policies and actions have been adopted by the Federal Government to combat the pandemic, which has even led to the setting of a Parliamentary Investigation Commission for the Pandemic (or for Covid-19) in the Federal Senate [15]. The late adoption of the National Plan for Vaccination against Covid-19, the slow pace of the population's vaccination schedule (until April 19, 2021 only 12.59\% of the population had taken one dose of vaccine and $4.78 \%$, two doses), among other factors, have contributed to the control failure of the pandemic in the country [16-18]. In addition, the dismantling of social policies to confront the FNI stands out, such as the extinction of the Conselho Nacional de Segurança Alimentar e Nutricional (CONSEA, National Council for Food and Nutritional Security), one of the first acts of the current government [19]. Lastly, the scenario would be even worse if Brazil did not have the Sistema Único de Saúde (SUS, Unified Health System), a public and universal health system for all its inhabitants, which may have contributed positively to reduce the number of cases and deaths [12,13].

Among the countries analyzed, according to the data in Table 1, Brazil stands close to the Human Development Index (HDI) of China, 0.761 and 0.758 respectively [20]. Between 2015 and 2017 there was a difference in the prevalence of malnourishment in the total population of these countries, $<2.5 \%$ in Brazil and $8.7 \%$ in China [21]. In more recent data, from 2017 to 2019, both countries had a prevalence $<2.5 \%$ of the total undernourished population [22]. In contrast, the number of infected people in China was 103,315 confirmed cases, with only 4,856 deaths ( 0.33 deaths per 100 thousand inhabitants), much lower than in Brazil, with 174.86 deaths per 100 thousand inhabitants, until 19 April 2021 [10]. Additionally, Brazil had a higher rate of extreme poverty and unemployment when compared to the other countries analyzed [23]. It should be noted that most of the indicators presented in Table 1 seek to portray the pre-pandemic situation across countries. In the case of the indicator "prevalence of malnourished people", for example, it expresses the context of structural hunger (that type of endemic, chronic or permanent hunger, resulting from unfair and unequal economic, social and political structures) already existing in those countries, to which was added the contingent of people affected by short-term hunger (a type of acute or transient hunger that can occur due to droughts, floods, wars and catastrophes in general) caused by the Covid-19 pandemic [24-27].

Apart from the differences between countries, the global situation with the pandemic is of concern. The United Nations Development Program (UNDP) estimated that, four months after the beginning of Covid-19 pandemic, there would be a substantial slump in family income in many countries, with global human development declining for the first time since 1990 [28]. The World Food Program also estimated for November 2020, the existence of 200,000 individuals in FNI and that such number would rise between 750,000 and 2.3 million by March 2021 with the persistence of Covid-19 [22]. The International Labor Organization (ILO) has warned of an increase in inequality and poverty in Latin America and the Caribbean, with a sharp increase in unemployment rates. Such an unemployment rate, which would tend to rise between 4 and 5 percentage points, could result in millions of unemployed people, disrupting the countries' economic and social stability [29]. According to the World Bank there would be a $7.2 \%$ drop in economic growth, leading to an unemployment rate of up to $12.3 \%$. This would imply a growth of 26 million people (before the pandemic) to 41 million people in 2020 who would be looking for a job without success. Thus, there would be deterioration in the quality of jobs and a reduction of family income [29].

The social and economic damages unleashed by the pandemic contribute together to aggravate the FNI's situation. In fact, the population increase of the FNI population has been growing dramatically since the beginning of the pandemic in Brazil and in the world [30-32]. In the USA, the pandemic caused a crisis of food insecurity never seen in that country. According to data of the Department of Agriculture, in the last five years, food insecurity has fluctuated around $11 \%$ to $12 \%$; however, in March and April 2020, food insecurity estimates rose to $38 \%$ in the USA [33].

It is observed, therefore, that the scenario involves many nuances to explain the figures presented, but the social inequalities due to the FNI are clearly associated with the risk of infection by Covid-19, exhibiting the biological vulnerability of an unequal human society. 


\section{FOOD AND NUTRITION INSECURITY AND OBESITY IN THE COVID-19 PANDEMIC}

In Brazil, the right of everyone to regular and permanent access to quality food, a constitutional guarantee of the National Food and Nutritional Security Policy, has been strongly affected by this pandemic, favoring FNI conditions [34-37].

Data from the Rede Brasileira de Pesquisa em Soberania e Segurança Alimentar (PENSSAN, Brazilian Research Network on Sovereignty and Food Security Network) show that, by the end of $2020,55.2 \%$ of the Brazilian population faced food insecurity conditions; $9 \%$ were in conditions of severe food insecurity, that is, hunger. These rates would be even higher in homes where some of the residents lost their jobs or got into debt due to the pandemic, causing a boost in the growth of the FNI observed in recent years in the country [38].

Structural hunger lasted for centuries in Brazil, but was overcome when undernourished people dropped from $10.7 \%$ to less than $5 \%$ in the first decade of this century [39]. In this connection, in 2014 a UN report was published attesting to the country's exclusion from the so-called Hunger Map, indicating that $3 \%$ of the population ingested fewer calories than recommended by the Food and Agriculture Organization (FAO) [40]. On the other hand, according to the Household Budget Surveys (HBS), in the 34 years from 1974-1975 to 2008-2009, the prevalence of obesity increased more than four times for men (from $2.8 \%$ to $12.4 \%$ ) and more than twice for women (from $8.0 \%$ to $16.9 \%$ ) [41]. More recent data from Vigitel (Surveillance of risk and protective factors for chronic diseases by telephone survey) indicate that obesity frequency in the Brazilian adults population ( $\geq 18$ years old, both genders) in the 26 capitals and in the Federal District between the years from 2006 to 2018 increased from $11.8 \%$ to $19.8 \%$ [42]. Therefore, $\mathrm{FNI}$, previously characterized by a quantitative food shortage ( $59.7 \%$ in 2004$)$, has become associated with obesity, related to higher energy consumption and lower micronutrients consumption, which reflected on the high rates of nutritional deficiencies presented by obese individuals [6,43-45].

We use the term structural obesity, to match the term structural hunger, generated by social inequality, misery and poverty and to be overcome demands fundamental economic, political and social changes [2427]. In this sense, obesity cannot be reduced to its biomedical definition of body fat accumulation harmful to health, as recommended by the World Health Organization (WHO) [46]. Just like hunger/malnutrition, obesity is generated by broader social and political complex factors associated with changes in the global food production system, aimed at increasing production and consumption of affordable and low nutritional quality food, also involving environmental issues [47-50].

There is evidence that the current pandemic break-down will substantially increase the FNI and obesity rates in the world [51]. However, this projected scenario will develop on different bases, depending on the prevalence, the degree of poverty and the support policies of the different nations. Obesity resulting from the increase in $\mathrm{FNI}$, can be explained by the tendency to increase the consumption of processed and ultraprocessed foods, as they are more accessible and practical, to the detriment of fresh (minimally processed) and regional foods [52,53]. It is noteworthy that, in Brazil, between the periods of the Household Budget Surveys (HBS) 2008-2009 and 2017-2018, prepared foods and industrial mixtures showed an increase of $56 \%$ in their average per capita quantities purchased. On the other hand, the flour, starch and pasta groups; cereals and pulses and dairy products showed the largest decreases in the acquisitions average among the three waves of HBSs (48\%, 43\%, and 36\%, respectively), covering the years 1974 to 2018. As to food acquisition according to the household situation, there was a greater share of fresh and minimally processed foods ( $57.9 \%$ against $47.7 \%$ of total calories) and processed culinary ingredients ( $25.3 \%$ against $21.7 \%$ ) in rural areas compared to urban areas. On the other hand, the share of processed and ultra-processed foods was higher in urban areas (11.3\% and $19.8 \%$, respectively) than in rural areas $(5.5 \%$ and $10.7 \%$, respectively) [54]. 
This condition can contribute to insulin resistance, obesity and the metabolic syndrome, which, associated with reduced physical activity in the pandemic and depression, provide immune dysfunction with less defense against infections [3,7,55]. Kamyari et al. (2021), with the objective of evaluating the effect of diet, nutrition, obesity and their implications on Covid-19 mortality, in a study involving 188 countries, observed that populations that consumed more eggs and cereals had higher rates of patients recovery. On the other hand, the effect of sugar consumption on mortality was considerable, with lower recovery rates in populations with higher sugar consumption [56]. In addition, low-grade chronic systemic inflammation, common in people with obesity, is associated, among others, with the development of type 2 diabetes mellitus, hypertension, cardiovascular disease and atherosclerosis, comorbidities that adversely affect patients with Covid-19 [1.11]. In fact, overweight and obesity were associated with an unfavorable early prognosis in patients with diabetes mellitus 2 (under the age of 75 years) hospitalized with Covid-19 in a French multicenter study ("Coronado study") [57]. In another study carried out in Italy, in the Tuscany region, obesity was associated with an increased risk of hospitalization in patients with Covid-19, especially in individuals under 70 years of age [58].

Obesity, considered a global epidemic by the WHO since 2000, has different prevalence among the countries analyzed in this study (Table 1) [59]. In the pre-pandemic Covid-19 scenario, obesity prevalence data in 2016 (\% of adults $>18$ years of age with Body Mass Index BMI $\geq 30 \mathrm{~kg} / \mathrm{m}^{2}$ ) were higher in the USA and Brazil. Interestingly, these same countries also had the highest rates of infection and death by Covid-19 in their populations. It is noteworthy that, although the number of obese people in China (using BMI as a parameter) is not as significant as in most countries analyzed (Table 1), it should be considered that individuals of Asian descent are prone to visceral fat storage, predisposing them to type 2 diabetes mellitus [60]. Despite this vulnerability, China's mortality data were low (Table 1).

It is likely that the greater food and nutritional vulnerability, especially in countries with greater social inequality, can make economically underprivileged population groups even more vulnerable from the immunological stand point [3,52]. Stress, in turn, can affect body weight status through biological, psychological and behavioral mechanisms, such as ingestion of more palatable and energy-dense foods, sleep disorders and decreased physical activity [8,9]. HBS data of 2017-2018 show significant differences between the classes with the lowest and highest total family income and the quantities of food purchased, with the highest-income group having higher averages in relation to the purchase of dairy products (176\% higher), vegetables (187\% higher) and fruits (313\% higher) [54].

Although still scarce, there is evidence that the immune function is impaired both by food shortages and the intake of high-energy and low-quality foods, represented by micronutrient deficiencies $[2,3,6]$. Thus, although there are differences in dietary patterns, unbalanced diets are a threat to global health and affect not only mortality rates, but also quality of life [56].

In the Covid-19 progression phase, immune and inflammatory responses particularly affect the lungs and immune organs, and the interaction of adipose tissue and the immune system can lead to disease severity and lethality $[2,3]$. In a recent systematic review with meta-analysis, obesity was considered a significant risk factor for admission to Intensive Care Units, and particularly for the need of invasive mechanical ventilation, in patients with Covid-19 [61].

Obesity may be, at least in part, a reflection of an individual's relationship with his/her environment. It can be associated with unemployment, social disadvantages and reduced socioeconomic productivity; it should be considered that people recovered from Covid-19 will need an adequate quality of life and may require a greater health care $[5,8]$.

According to the above, the health disparities observed in vulnerable individuals may explain, in part, the differences in the health situation in coping with Covid-19 [52]. 
As this study deals with reflections on aspects related to a pandemic that is still ongoing and with dynamic evolution, this paper has limitations. Due to the lack of conclusive data on different outcomes, estimated or indirect data were used, such as the number of unemployed individuals living below the poverty line as a result of the pandemic. The analysis exercise carried out, albeit burgeoning, intends to show what facial masks cannot hide: FNI and social inequalities, aggravated by this pandemic, in addition to the damage caused by the disease itself, expose the social ailments with biological consequences both regarding the risk of infection as well as an aggravating factor of its onset.

\section{CONCLUSION}

Social and biological vulnerability in the condition of poverty are synergistic and can condemn segments of the population to the worsening of inequalities with regard to exposure, risk and severity of the disease. A vicious circle providing feed-back: FNI jeopardizes the individual's nutritional status and health, which in turn makes individuals vulnerable to worse prognoses, while the spreading of the pandemic aggravates FNI conditions. In this scenario, the need for immediate Food and Nutritional Security (FNS) actions at different governmental levels is urgent, in order to mitigate the impact and reduce the consequences of the Covid pandemic [19].

\section{CONTRIBUTORS}

AM ABREU, CC PALAZZO, BP BARBOZA, E WAZLAWIK, RW DIEZ-GARCIA and FAG VASCONCELOS contributed at all stages: conception and design of the study; participation in the bibliographic search; collection and interpretation of data; writing of the manuscript and approval of the final version.

\section{REFERENCES}

1. Chiappetta S, Sharma AM, Bottino V, Stier C. Covid-19 and the role of chronic inflammation in patients with obesity. Int J Obes. 2020;44(8):1790-2. https://doi.org/10.1038/s41366-020-0597-4

2. Petrakis D, Margină D, Tsarouhas K, Tekos F, Stan M, Nikitovic D, et al. Obesity a risk factor for increased Covid-19 prevalence, severity and lethality (Review). Mol Med Rep. 2020;22(1):9-19. https://doi.org/10.3892/ mmr.2020.11127

3. Nieman DC. Coronavirus disease-2019: a tocsin to our aging, unfit, corpulent, and immunodeficient society. J Sport Health Sci. 2020;9(4):293-301. https://doi.org/10.1016/j.jshs.2020.05.001

4. United Nations. World economic situation and prospects as of mid-2020. Genebra: United Nations; 2020 [cited 2021 Feb. 19]. Available from: https://www.un.org/development/desa/dpad/publication/world-economic-situationand-prospects-as-of-mid-2020/

5. Butler MJ, Barrientos RM. The impact of nutrition on Covid-19 susceptibility and long-term consequences. Brain Behav Immun. 2020;87:53-4. https://doi.org/10.1016/j.bbi.2020.04.040

6. Dhurandhar EJ. The food-insecurity obesity paradox: a resource scarcity hypothesis. Physiol Behav. 2016;162:88-92. https://doi.org/10.1016/j.physbeh.2016.04.025

7. Zobel EH, Hansen TW, Rossing P, von Scholten BJ. Global changes in food supply and the obesity epidemic. Curr Obes Rep. 2016;5(4):449-55. https://doi.org/10.1007/s13679-016-0233-8

8. Blüher M. Obesity: global epidemiology and pathogenesis. Nat Rev Endocrinol. 2019;15(5):288-98. https://doi. org/10.1038/s41574-019-0176-8

9. Abbas AM, Fathy SK, Fawzy AT, Salem AS, Shawky MS. The mutual effects of Covid-19 and obesity. Obes Med. 2020;19:100250. https://doi.org/10.1016/j.obmed.2020.100250 
10. World Health Organization. Coronavirus Disease (Covid-19) Dashboard. Genebra: Organization; 2020 [cited 2021 Apr 19]. Available from: https://covid19.who.int/

11. Stefan N, Birkenfeld AL, Schulze MB, Ludwig DS. Obesity and impaired metabolic health in patients with Covid-19. Nat Ver Endocrinol. 2020;16(7):341-2. https://doi.org/10.1038/s41574-020-0364-6

12. Oliveira WK, Duarte E, França GVA, Garcia LP. Como o Brasil pode deter a Covid-19. Epidemiol e Serv Saúde Rev do Sist Único Saúde do Bras. 2020 [Acessado em 19 de fevereiro de 2021];29(2):e2020044. https://doi.org/10.5123/ s1679-49742020000200023

13. Costa AM, Rizzotto MLF, Lobato L de VC. Na pandemia da Covid-19, o Brasil enxerga o SUS. Saúde em Debate. 2020;44(125):289-96. https://doi.org/10.1590/0103-1104202012500

14. Gee J, Marquez P, Su J, Calvert GM, Liu R, Myers T, et al. First month of Covid-19 vaccine safety monitoring: United States, December 14, 2020-January 13, 2021. Morb Mortal Wkly Rep. 2021;70:283-8. https://doi.org/10.15585/ mmwr.mm7008e3

15. Senado Federal (Brasil). CPI da Covid é criada pelo Senado. Brasília: Senado Federal; 2021 [cited 2021 Apr 22]. Available from: https://www12.senado.leg.br/noticias/materias/2021/04/13/senado-cria-cpi-da-covid

16. Ministério da Saúde (Brasil). Plano Nacional de Operacionalização da Vacinação contra a Covid-19. Brasília: Ministério; 2020 [cited 2021 Apr 22]. Available from: https://www.gov.br/saude/pt-br/media/pdf/2020/dezembro/16/plano_ vacinacao_versao_eletronica-1.pdf

17. Neiva MB, Carvalho I, Costa Filho TS, Barbosa-Junior F, Bernardi FA, Sanches TLM, et al. Brazil: the emerging epicenter of Covid-19 pandemic. J Br Soc Trop Med. 2020;53. https://doi.org/10.1590/0037-8682-0550-2020

18. Brasil aplicou ao menos uma dose de vacina contra Covid em 26,6 milhões de pessoas, aponta consórcio de veículos de imprensa. G1, São Paulo, 19 de abril de 2021 [cited 2021 Apr 22]. Available from: https://g1.globo. com/bemestar/vacina/noticia/2021/04/19/brasil-aplicou-ao-menos-uma-dose-de-vacina-contra-covid-em-266milhoes-de-pessoas-aponta-consorcio-de-veiculos-de-imprensa.ghtml

19. Recine E, Fagundes A, Silva BL, Garcia GS, Ribeiro RCL, Gabriel CG. Reflections on the extinction of the National Council for Food and Nutrition Security and the confrontation of Covid-19 in Brazil. Rev Nutr. 2020;33:e200176. https://doi.org/10.1590/1678-9865202033e200176

20. United Nations. Human Development Data (1990-2018): Human Development Reports. Geneva: United Nations; 2019 [cited 2021 Fev 19]. Available from: http://hdr.undp.org/en/data

21. Organización de las Naciones Unidas para la Alimentación y la Agricultura. El estado de la seguridad alimentaria y la nutrición e nel mundo. Fomentando la resiliencia climática en aras de la seguridad alimentaria y la nutrición. 2018;131-50. [cited 2021 Feb 19]. Available from: http://www.fao.org/3//9553ES/i9553es.pdf

22. FAO, IFAD, UNICEF, WFP, WHO. The State of Food Security and Nutrition in the World 2020. Transforming food systems for affordable healthy diets. Rome: FAO; 2020 [cited 2021 Feb 19]. Available from: http://www.fao.org/ documents/card/en/c/ca9692en

23. The World Bank. Poverty and Equity: DataBank. Washigton: The World Bank; 2020 [cited 2021 Feb 19] Available from: https://databank.worldbank.org/source/poverty-and-equity\#selectedDimension_PovStats_Ctry

24. Valente FLS. Fome, desnutrição e cidadania: inclusão social e direitos humanos. Saúde Soc. 2003;12(1):51-60. https://doi.org/10.1590/s0104-12902003000100008

25. Rosaneli CF, Ribeiro ALC, Assis L, Silva TM, Siqueira JE. A fragilidade humana diante da pobreza e da fome. Rev Bioética. 2015;23(1):89-97. https://doi.org/10.1590/1983-80422015231049

26. Vasconcelos FDAG. Josué de Castro and the geography of hunger in Brazil. Cad Saúde Pública. 2008;24(11):27107. https://doi.org/10.1590/s0102-311×2008001100027

27. Ziegler J. Destruição em massa: geopolítica da fome. São Paulo: Cortez; 2013.

28. United Nations. Covid-19 and human development: assessing the crisis, envisioning the recovery, report, May, 2020. Genebra: United Nations; 2020 [cited 2021 Feb 19]. Available from: http://hdr.undp.org/en/hdp-covid

29. Organização Internacional do Trabalho. Panorama Laboral em tiempos de la Covid-19 impactos em el mercado de trabajo y los ingresos en América Latina y el Caribe. 2020;1-23. [cited 2021 Feb 19]. Available from: https://www. ilo.org/brasilia/noticias/WCMS_749687/lang--pt/index.htm 
30. Ribeiro-Silva RC, Pereira M, Campello T, Aragão É, Guimarães JM M, Ferreira AJF, et al. Implicações da pandemia Covid-19 para a segurança alimentar e nutricional no Brasil. Ciênc Saúde Coletiva. 2020;25(9):3421-30. https:// doi.org/10.1590/1413-81232020259.22152020

31. Niles MT, Bertmann F, Belarmino EH, Wentworth T, Biehl E, Neff R. The early food insecurity impacts of Covid- 19 . Nutrients. 2020;12(7). https://doi.org/10.3390/nu12072096

32. O'Hara S, Toussaint EC. Food access in crisis: Food security and Covid-19. Ecol Econ. 2021;180:106859. https://doi. org/10.1016/j.ecolecon.2020.106859

33. Wolfson JA, Leung CW. Food insecurity during Covid-19: an acute crisis with long-term health implications. 2020;110:1763-5. Ame J Public Health. https://doi.org/10.2105/AJPH.2020.305953

34. Ministério da Saúde (Brasil). Política Nacional de Alimentação e Nutrição. 2013 [cited 2021 Feb 19]. Available from: https://bvsms.saude.gov.br/bvs/publicacoes/politica_nacional_alimentacao_nutricao.pdf

35. Jaime PC. The Covid-19 pandemic: implications for food and nutrition (in)security. Ciênc Saúde Coletiva. 2020;25(7):2505. https://doi.org/10.1590/1413-81232020257.12852020

36. Silva Filho OJ, Gomes Júnior NN. O amanhã vai à mesa: abastecimento alimentar e Covid-19. Cad Saúde Pública. 2020;36(5):e00095220. https://doi.org/10.1590/0102-311x00095220

37. Oliveira TC, Abranches MV, Lana RM. (In)Segurança alimentar no contexto da pandemia por SARS-CoV-2. Cad Saúde Pública. 2020;36(4):e00055220. https://doi.org/10.1590/0102-311X00055220

38. Rede Brasileira de Pesquisa em Soberania e Segurança Alimentar e Nutricional. VIGISAN: Inquérito Nacional Sobre Insegurança Alimentar no Contexto da Pandemia da Covid-19 no Brasil. 2021 [cited 2021 Apr 22]. Available from: http://olheparaafome.com.brNIGISAN_Inseguranca_alimentar.pdf

39. Prado SD. Segurança Alimentar e Nutricional no Brasil. Ciênc Saúde Coletiva. 2009;15(1). https://doi.org/10.1590/ S1413-81232009011000001

40. Organização das Nações Unidas para Alimentação e Agricultura. FAO no Brasil: Brasil em resumo. Roma: Organização; 2019 [cited 2021 Feb 19]. Available from: http://www.fao.org/brasil/fao-no-brasil/brasil-em-resumo/ pt/

41. Instituto Brasileiro de Geografia e Estatística. Pesquisa de Orçamentos Familiares 2008-2009: Análise do Consumo Alimentar Pessoal no Brasil. Rio de Janeiro: Instituto; 2011 [cited 2021 Feb 19]. Available from: https://biblioteca. ibge.gov.br/visualizacao/livros/liv50063.pdf

42. Ministério da Saúde (Brasil). Vigitel: estimativas sobre frequência e distribuição sociodemográfica de fatores de risco e proteção para doenças crônicas nas capitais dos 26 estados. Brasília: Ministério; 2019. [cited 2021 Feb 19]. Available from: http://bvsms.saude.gov.br/bvs/publicacoes/vigitel_brasil_2018

43. Instituto Brasileiro de Geografia e Estatística. Pesquisa Nacional por Amostra de Domicílios: Segurança Alimentar 2004/2009. Rio de Janeiro: Instituto; 2010 [cited 2021 Feb 19]. Available from: http://biblioteca.ibge.gov.br/ visualizacao/livros/liv47241.pdf

44. Kaidar-Person O, Person B, Szomstein S, Rosenthal RJ. Nutritional deficiencies in morbidly obese patients: a new form of malnutrition? Part A: vitamins. Obes Surg. 2008;18(7):870-6. https://doi.org/10.1007/s11695-007-9349-y

45. Kaidar-Person O, Person B, Szomstein S, Rosenthal RJ. Nutritional deficiencies in morbidly obese patients: a new form of malnutrition? Part B: minerals. Obes Surg. 2008;18(8):1028-34. https://doi.org/10.1007/s11695-0079350-5

46. World Health Organization. Obesity and Overweight: key facts. 2020;1913-5. [cited 2021 Feb 19]. Available from: https://www.who.int/news-room/fact-sheets/detail/obesity-and-overweight

47. Swinburn BA, Kraak VI, Allender S, Atkins VJ, Baker PI, Bogard JR, et al. The global syndemic of obesity, undernutrition, and climate change: the lancet commission report. Lancet. 2019;93:791-846. https://doi.org/10.1016/S0140$6736(18) 32822-8$

48. Swinburn BA, Sacks G, Hall KD, McPherson K, Finegood DT, Moodie ML, et al. The global obesity pandemic: shaped by global drivers and local environments. Lancet. 2011;378(9793):804-14. https://doi.org/10.1016/S01406736(11)60813-1

49. Alcaraz JPH, Ramírez JP, Peinado MEL. Updating the sociocultural approaches to obesity: proposals from hacking, Bourdieu and Foucault. Physis. 2020;30(3):1-21. https://doi.org/10.1590/S0103-73312020300322 
50. Gracia Arnaiz M, Demonte F, Kraemer FB. Prevenir la obesidad en contextos de precarización: respuestas locales a estrategias globales. Salud Colect. 2020;16:e2838. https://doi.org/10.18294/sc.2020.2838

51. Nouh F, Elfagi S, Omar M. Corona virus: the Paradox between Food Insecurity and Weight Gain. EAS J Nutr Food Sci. 2020;39-43. https://doi.org/10.36349/easjnfs.2020.v02i02.07

52. Costa Louzada ML, Baraldi LG, Steele EM, Martins APB, Canella DS, Moubarac J-C, et al. Consumption of ultraprocessed foods and obesity in Brazilian adolescents and adults. Prev Med (Baltim). 2015;81:9-15. https://doi. org/10.1016/j.ypmed.2015.07.018

53. Vandevijvere S, Jaacks LM, Monteiro CA, Moubarac JC, Girling-Butcher M, Lee AC, et al. Global trends in ultraprocessed food and drink product sales and their association with adult body mass index trajectories. Obes Rev. 2019;20(S2):10-9. https://doi.org/10.1111/obr.12860

54. Instituto Brasileiro de Geografia e Estatística. Pesquisa de orçamentos familiares 2017-2018: primeiros resultados. Rio de Janeiro: Instituto; 2019 [cited 2021 Feb. 19]. Available from: https://biblioteca.ibge.gov.br/index.php/ biblioteca-catalogo?view=detalhes\&id=2101597

55. Zheng L, Sun J, Yu X, Zhang D. Ultra-processed food is positively associated with depressive symptoms among United States adults. Front Nutr. 2020;7:600449. https://doi.org/10.3389/fnut.2020.600449

56. Kamyari N, Soltanian AR, Mahjub H, Moghimbeigi A. Diet, nutrition, obesity, and their implications for Covid-19 mortality: development of a marginalized two-part model for semicontinuous data. JMIR Public Heal Surveill. 2021;7(1):e22717. https://doi.org/10.2196/22717

57. Smati S, Tramunt B, Wargny M, Caussy C, Gaborit B, Vatier C, et al. Relationship between obesity and severe Covid-19 outcomes in patients with type 2 diabetes: results from the CORONADO study. Diabetes Obes Metab. 2021;23(2):391-403. https://doi.org/10.1111/dom.14228

58. Bellini B, Cresci B, Cosentino C, Profili F, Bartolacci S, Scoccimarro D, et al. Obesity as a risk factor for hospitalization in CoronaVirus Disease-19 (Covid-19) patients: analysis of the Tuscany regional database. Nutr Metab Cardiovasc Dis. 2021;31(3):769-73 https://doi.org/10.1016/j.numecd.2020.11.030

59. World Heath Organization. Obesity: Preventing and Managing the Global Epidemic of Obesity. Report of a WHO Consultation (WHO Technical Report Series 894). Geneva: Organization; 2000 [cited 2021 Fev 19]. Available from: https://www.who.int/nutrition/publications/obesity/WHO_TRS_894/en/

60. Hu C, Jia W. Diabetes in China: epidemiology and genetic risk factors and their clinical utility in personalized medication. Diabetes. 2018;67(1):3-11. https://doi.org/10.2337/dbi17-0013

61. Földi M, Farkas N, Kiss S, Zádori N, Váncsa S, Szakó L, et al. Obesityis a risk factor for developing critical condition in Covid-19 patients: a systematic review and meta-analysis. Obesity Reviews. 2020:21;e13095. https://doi. org/10.1111/obr.13095

62. The World Bank. Health Nutrition and Population Statistics: population estimates and projections. Washington: The World Bank; 2016 [cited 2021 Feb 19]. Available from: https://databank.worldbank.org/source/health-nutritionand-population-statistics/Type/TABLE/preview/on 